\title{
How to Start a New Medical Journal?
}

To strive with difficulties, and to conquer them, is the highest human felicity.

-Samuel Johnson, English Essayist (1709-1784)

\subsection{Why Should We Start a Medical Journal?}

A medical journal encourages research and promotes publication from the institution which publishes it [1]. Many of the best academic institutions abroad and in India publish medical journals, e.g., the Mayo Clinic (Mayo Clinic Proceedings) in the USA and the All India Institute of Medical Sciences (The National Medical Journal of India).

\subsection{What Are the Ten Most Important Steps Before Starting a Journal?}

Starting a journal is a major commitment and cannot be done alone. It requires teamwork with like-minded people. Most of the editorial work is honorary and only people interested in academics should be entrusted to take this on. The editorial and working committee of the journal require determination, time commitment, and passion to produce a journal of high quality.

The important steps before thinking of starting a new journal are [2]:

- Step-1 Understand the need for starting a new journal. It could be a new field, a journal based on an unusual theme or a hospital-based multi-speciality journal.

- Step-2 Appoint an Editor, who will lead the team and will be responsible for the scientific content published.

- Step-3 Then appoint a Working Committee from within the local talent and representing many different specialties. These dedicated people should hold weekly meetings initially to work on the logistics for launching the journal. 
- Step-4 Invite an Editorial Board of approximately sixteen well-known physicians who would be willing to help. There should be at least eight from abroad.

- Step-5 Ask for a dedicated office, computer, Internet access, and start designing a website.

- It is useful to have an 'Editorial Assistant' who receives and checks manuscripts, sends them to reviewers, and interacts with the publisher.

- Step-6 Work on a name for the journal. The name should be catchy, concise, and reflect what the expected contents will be. The title should be attractive, informative, unusual, and perhaps unique. Not 'Proceedings of the ...' but 'Quality Health care in the Himalayan Foothills'.

- Step-7 Work on getting a good publisher. This is a major task and in medicine the top publishers are Springer Nature Publishing, Oxford University Press, Taylor \& Francis Publishing, Wolters Kluwer, and Elsevier.

- Step-8 Call for papers. To get manuscripts will be difficult initially as the journal will not be indexed. Depend on the local institutional talent, your friends and acquaintances here and abroad, and subsequently through online advertisements and displaying it in major conferences.

- Step-9 Try and produce a 'world class' journal from the first few issues which should influence decision makers in science.

- Step-10 Register the journals on various portals like a web of science, PubMed, and Scopus to disseminate knowledge about journals and articles published.

\subsection{What Kind of Articles Should We Publish? How Do We Plan a Table of Contents?}

The Editorials should first be written by the Editor, e.g., 'Why this Journal?' Later they should be invited, and discuss general topics or comment on papers published in that particular issue. We believe that the editorials should be signed.

The next section should be on Original Articles; initially requested from friends, faculty, and students preferably from other institutions on basic, clinical, and paraclinical sciences. They should all be sent for peer review to two or three experts one of whom should be foreign.

Review articles should be commissioned from known authorities and although sent for review but should generally be accepted.

Then should follow Short Reports, Selected Summaries (precis and commentary on articles published elsewhere), a section for General Practitioners and Students, reports of Clinicopathological Conferences, a Speaking for Myself or Medicine and Society Section and perhaps a profile of a great medical man or institution here or abroad. There should be a special section on 'Letters to the Editor'.

\subsection{What Are the General Guidelines for Publishing the Journal?}

Always start a journal using peer reviewers. This not only improves the quality of articles published in the journal but also it is standing among the scientific community. Few general instructions are [3]: 
- Insist on Quality, Class, and Excellence in the article published.

- The number of pages per issue should be at least 48 pages and thereafter in multiples of four.

- The Cover should have a simple design perhaps displaying the table of contents.

- Choose good quality paper, have a two-column layout, and make provision to have both black and white and colour illustrations (Fig. 36.1).

\title{
Y CURRENT MEDICINE GRENere RESEARCH \& PRACTICE
}

\author{
ORIGINAL ARTICLES \\ The research output from Indian medical institutions between 2005 and 2014 \\ Apolipoprotein levels in type 2 diabetes mellitus patients \\ Pathophysiological basis of hemornhoidal treatment \\ REVIEW ARTICLES \\ Optimixing outcomes of colorectal surgery-the current perspectives \\ Growth charts in neonates
}

CASE RE.PORTS

Admixed foamy cell and signet ring cell change in a cutanoous angiosarcoma-a diagnostic pitfall Acute tubercular appendicitis: A rare presentation

Mollaret's meningitis and enterovinus infection

Fig. 36.1 Simple cover of Medical Journal with table of contents (with permission of editor CMRP) 
- Choose a good printing press for the paper copy and post the online issue on your website.

- Apply for an International Standard Serial Number (ISSN). This is an eight-digit unique number given to all journals by the Registrar of Newspapers of India.

\subsection{What Discussions Should We Have with the Publisher When Planning a Journal?}

Discuss the general layout of the journal and the paper's quality. The other things to be discussed are its format, whether it is open access or closed, free online, or requiring a subscription. Also, discuss revenue sharing between the institution and publisher from subscriptions and also from advertisements. Decide the frequency of publication, i.e., monthly, bimonthly, or quarterly.

Write. Write. Write.

Will anyone care about these words or journal...?

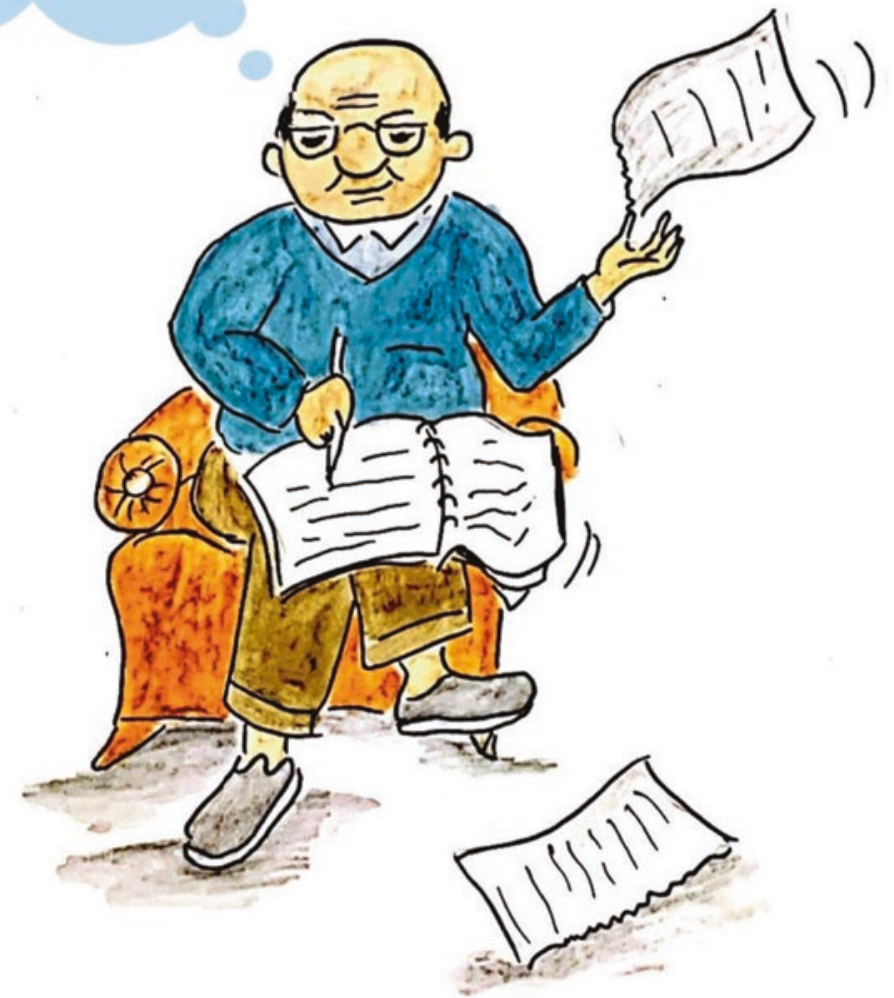




\subsection{What Should Be the Agenda for Weekly Working Task Force Meetings?}

The members of the working task force are the main people who will run the journal. They should be responsible for:

- Sending letters of invitation for articles to potential authors-constantly and regularly.

- The whole process of submitting articles, receiving them, sending to reviewers to accept, modify or reject, making an editorial decision to accept, forwarding to the printer, checking the PDFs can all be done using an Editorial Manager software programme.

- Try and maintain a high standard of content, layout, and quick decision-making on the submissions.

- Ensure that the journal is published and always comes out on time. The online version should always be followed by a print version.

- After 2 years of regular publication apply for indexing to Medline.

\subsection{What Are the Challenges Which the Journal May Face During Its Initial Days?}

It is usually believed that if a journal is able to survive for two years it may be able to exist for the long term. The major challenges which the journal may face in the future are $[4,5]$ :

1. Financial crises - the start of a journal requires a good amount of seed money and then there are recurring costs of printing per issue and also the cost of manpower in running the office. The open access model where the authors pay processing fees and subscriptions and advertisements can be the three sources of income for the journal.

2. Inability to get good content scientific articles. There is a vicious cycle that till the journal is indexed it may not be able to get quality articles. Till then all the articles that are received by the journal may have to be raised to better quality by the working committee.

3. Inability to get indexed with different scientific portals.

4. Poor English is also encountered in many manuscripts, especially when it is from non-English speaking countries.

5. Reluctance to do peer review is a process that is very time consuming.

\subsection{Conclusions}

- Starting a new journal is a difficult task and sustaining it is even more difficult.

- It is not a one-man show and requires a team effort. One of the pre-requisites is to include a competent experienced, hardworking, and enthusiastic editorial team.

- A major hurdle for the journal is to be indexed with different agencies. Once this is done the journal may be able to survive and flourish. 


\section{References}

1. Tullu MS, Karande S. Quality research in Indian medical colleges and teaching institutions: the need of the hour. J Postgrad Med. 2016;62:213-5.

2. Deciding to Launch a New Journal. Last accessed on 22nd July 2020. Available on https:// www.elsevier.com/editors-update/story/publishing-trends/deciding-to-launch-a-new-journal.

3. Jawaid SA, Jawaid M. How to run a successful journal. Pak J Med Sci. 2017;33:1517-20.

4. Nayak BK. Naunces of starting a new medical journal. J Clin Ophthalmol Res. 2013;1:135-6.

5. Trikha A. On starting a new medical journal; problems, challenges, and remedies. Indian Anaesth Forum. 2016;17:3-5.

Open Access This chapter is licensed under the terms of the Creative Commons Attribution 4.0 International License (http://creativecommons.org/licenses/by/4.0/), which permits use, sharing, adaptation, distribution and reproduction in any medium or format, as long as you give appropriate credit to the original author(s) and the source, provide a link to the Creative Commons license and indicate if changes were made.

The images or other third party material in this chapter are included in the chapter's Creative Commons license, unless indicated otherwise in a credit line to the material. If material is not included in the chapter's Creative Commons license and your intended use is not permitted by statutory regulation or exceeds the permitted use, you will need to obtain permission directly from the copyright holder. 